Article

\title{
A Preliminary Comparison of Antioxidants of Tomato Fruit Grown Under Organic and Conventional Systems
}

\author{
Apiradee Uthairatanakij ${ }^{1}{ }^{*}$, Sukanya Aiamla-or ${ }^{1}$, Pongphen Jitareerat ${ }^{1}$ and \\ Ashariya Maneenoi ${ }^{2}$ \\ 1 Division of Postharvest Technology, King Mongkut's University of Technology Thonburi, Bangkok 10150, \\ Thailand; sukanyamlr@gmail.com (S.A.); pongphen.jit@kmutt.ac.th (P.J.) \\ 2 Lake Rajada Office, Adams Enterprises Ltd., Bangkok 10110, Thailand; ashariya@yahoo.com \\ * Correspondence: apiradee.uth@kmutt.ac.th; Tel.: +66-2-470-7724; Fax: +66-2-452-3750
}

Academic Editors: Varit Srilaong, Mantana Buanong, Chalermchai Wongs-Aree, Sirichai Kanlayanarat and Douglas D. Archbold

Received: 7 December 2015; Accepted: 9 September 2016; Published: 30 December 2016

\begin{abstract}
Organic farming is rapidly growing due to its perceived potential for producing higher nutritional quality. However, studies of organically- and conventionally-grown crops have not always shown differences between the systems. The objective of this research was to compare the antioxidant activities of organically-grown tomato to those from a conventional production system during postharvest cold storage. "Tub Tim Dang" tomato (Solanum lycopersicum L.) fruit were harvested at the breaker stage of maturity from both organic and conventional farms. Fruit were cold-stored at $10{ }^{\circ} \mathrm{C}$ for 20 days, and samples were collected at intervals to measure the activities of superoxide dismutase (SOD), catalase (CAT) and ascorbate peroxidase (APX) activities, and total antioxidant activity by the 2,2'-diphenyl-1-picrylhydrazyl (DPPH) and ferric reducing antioxidant power (FRAP) assays. The activities of SOD, CAT and APX of organic tomato fruit did not differ from those of conventional fruit during cold storage. In addition, there was no effect of production system on FRAP activity. In contrast, DPPH activity of organic tomato fruit was lower than conventional fruit through 10 days of cold storage, but it was higher at 15 and 20 days. These results indicated that organic production did not have a significant effects on these antioxidant traits of tomato.
\end{abstract}

Keywords: tomato; antioxidant enzyme; DPPH; FRAP

\section{Introduction}

Currently, many consumers are health conscious and aware of food quality, food safety and environmental protection, leading to an increasing demand for organic fresh products. Numerous studies on organic versus conventional crops have shown that organic fresh produce has significantly less chemical residue and greater nutritional content, including ascorbic acid, vitamin $\mathrm{E}, \beta$-carotene and phenolics [1-5]. However, the differences in chemical composition between organic and conventional produce is dependent on cultural practices and environmental factors, such as time of harvest, fertilizer, water supply and soil properties [6-8]. Tomato (Solanum lycopersicum L.) fruit have high economic value and popularity in the consumer's diet, and are an important nutritional source of antioxidants [9]. Antioxidant content may change during the ripening of tomato, and this is reflected in changes in the antioxidant activity [10].

Reactive oxygen species (ROS) are generated during normal metabolism and also under stress conditions, and are eliminated by the antioxidant system [11]. Antioxidant enzymes, including superoxide dismutase (SOD), catalase (CAT) and ascorbate peroxidase (APX), and free radical scavengers provide defense mechanisms against ROS [12]. SOD is found in the chloroplast and cytosol, 
and is a key antioxidant enzyme that catalyzes conversion of superoxide radicals into dioxygen and hydrogen peroxide $[13,14]$. Afterwards, hydrogen peroxide is eliminated by CAT or APX. CAT is located in the peroxisome and removes hydrogen peroxide without reducing agents, while APX is located in the chloroplast and cytosol and requires ascorbate as an electron donor to eliminate hydrogen peroxide in the plant cell $[15,16]$. SOD, CAT and APX are therefore efficient antioxidant enzymes for detoxifying ROS because they are located in all compartments of the cell.

Some antioxidant levels are believed to be higher in organic produce that are activated by natural mechanisms of the plant defense systems against pests and diseases or other stress factors [17]. Therefore, the aim of this study was to compare total antioxidant activity and activity of the antioxidant enzymes SOD, CAT, and APX of organically- and conventionally-grown tomato fruit.

\section{Experimental Section}

\subsection{Plant Preparation}

"Tub Tim Dang" tomato seeds were planted in January 2013 under both organic and conventional management systems. Both farms were located in Phakthongchai district, Nakonratchasima province, Thailand $\left(14^{\circ} 35^{\prime}-15^{\circ} 00^{\prime}\right.$ latitude, $101^{\circ} 45^{\prime}-102^{\circ} 15^{\prime}$ longitude) approximately $10 \mathrm{~km}$ apart. The organic tomato plants were grown according to the standard protocol used by Adam Enterprises, Ltd. (certified by the United States Department of Agriculture, Bangkok, Thailand). Before transplanting the organic tomato seedlings, $40 \mathrm{MT} \cdot \mathrm{ha}^{-1}$ of composted manure was applied to the soil. Then, fertilizer from fermented fish $\left(100 \mathrm{~mL} \cdot\right.$ plant $\left.^{-1}\right)$ was applied three times a week until harvest. Conventional tomato fruit were grown on farms that followed Good Agricultural Practices. Before transplanting, $187.5 \mathrm{~kg} \cdot \mathrm{ha}^{-1}$ of NPK starter fertilizer (15-15-15) was applied to the soil. The plants were side-dressed with fertilizer 10 days after transplanting with $62.5 \mathrm{~kg} \cdot$ hectare $^{-1}$ of $46-0-0$, with $187.5 \mathrm{~kg} \cdot \mathrm{ha}^{-1}$ of 15-15-15 NPK at 25 days, and with $187.5 \mathrm{~kg} \cdot \mathrm{ha}^{-1}$ of 13-13-21 NPK at 40 days. Irrigation was provided when it was necessary to avoid drought stress. Approximately $20 \mathrm{~kg}$ of fruit was harvested from both farms at the breaker stage, 55 days after transplanting. Fruit were washed with tap water, and placed in baskets before storage at $10{ }^{\circ} \mathrm{C}$ and $90 \% \mathrm{RH}$, where they started to ripen as indicated by fruit color change. At 0, 5, 10, 15 and 20 days of cold storage, about 30 fruit were randomly selected for a total approximate weight of $500 \mathrm{~g}$ and divided into three replicates. On the sampling day, tissues were frozen in liquid nitrogen and stored at $-20{ }^{\circ} \mathrm{C}$ until analysis. From each replicate, $3 \mathrm{~g}$ of frozen sample was allocated for 2,2'-diphenyl-1-picrylhydrazyl (DPPH) and ferric reducing antioxidant power (FRAP) assays. For each analysis of enzyme activity, $5 \mathrm{~g}$ of frozen sample was used.

\subsection{Total Antioxidant Activity}

DPPH and FRAP assays followed the method of Brand-Williams et al. [18] and Benzie and Strain [19], respectively, using a spectrophotometer. A standard curve between 25 and $800 \mu \mathrm{M}$ Trolox was linear, and results are expressed in Trolox equivalent antioxidant activity (TEAC) $\cdot \mathrm{g}^{-1} \cdot \mathrm{FW}$.

\subsection{Enzyme Assay}

For enzyme assays, $5 \mathrm{~g}$ of fruit tissue was homogenized in $10 \mathrm{~mL}$ cold extraction buffer $(0.05 \mathrm{M}$ sodium phosphate buffer, $\mathrm{pH}$ 7.8). The homogenate was filtered through a muslin cloth and centrifuged at $15,000 \mathrm{rpm}$ for $20 \mathrm{~min}$ at $4{ }^{\circ} \mathrm{C}$. The supernatant was used as a crude extract for SOD activity assays [20]. For the CAT and APX assays, $5 \mathrm{~g}$ of fruit tissue was homogenized in $10 \mathrm{~mL}$ of cold $0.1 \mathrm{M}$ phosphate buffer at $\mathrm{pH}$ 7.0. The homogenate was filtered through a muslin cloth and centrifuged at $15,000 \mathrm{rpm}$ at $4{ }^{\circ} \mathrm{C}$ for $20 \mathrm{~min}$. The supernatant was used as a crude extract for CAT and APX activities [21].

The SOD activity was determined based on its capacity to inhibit the reduction of nitro-blue tetrazolium (NBT) by superoxide radicals generated by xanthine oxidase. One SOD unit was expressed as the amount of extract with percent inhibition of NBT reduction [22]. CAT activity was measured at 
$240 \mathrm{~nm}$ for decomposition of $\mathrm{H}_{2} \mathrm{O}_{2}(\mathrm{mM}) \cdot \mathrm{min}^{-1}$ at $25^{\circ} \mathrm{C}$ [23]. APX activity measured the decrease of ascorbic acid at $290 \mathrm{~nm}$, and the result was expressed as $\mathrm{mM}$ ascorbic acid. $\mathrm{min}^{-1}$ at $28^{\circ} \mathrm{C}$ [24]. Three replicates were performed for each main treatment, organic and conventional, and each reaction was repeated 3 times.

\subsection{Statistical Analysis}

Microsoft Excel (Redmond, WA, USA) was used to perform statistical analyses with a paired $t$-test to compare organic versus conventional means.

\section{Results}

\subsection{2,2'-Diphenyl-L-Picrylhydrazyl (DPPH)}

The DPPH assay indicated a significant difference between organic and conventional tomato fruit, with generally higher levels from the conventional system during the first 10 days of storage, while organic tomato fruit showed significantly higher levels than conventional fruit on days 15 and 20 (Figure 1A).

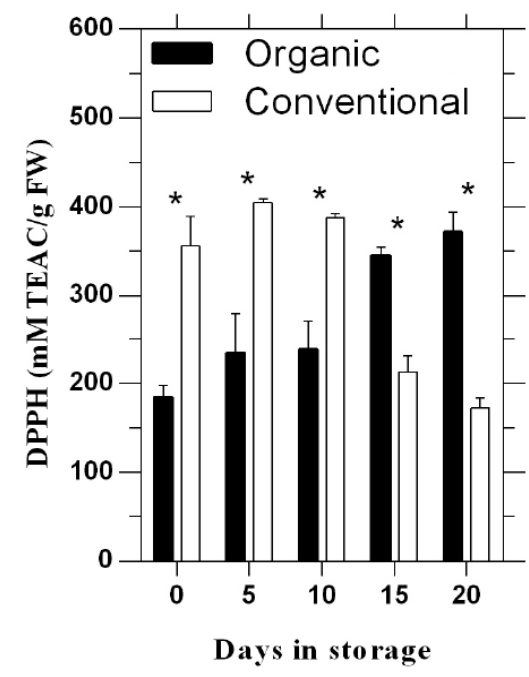

(A)

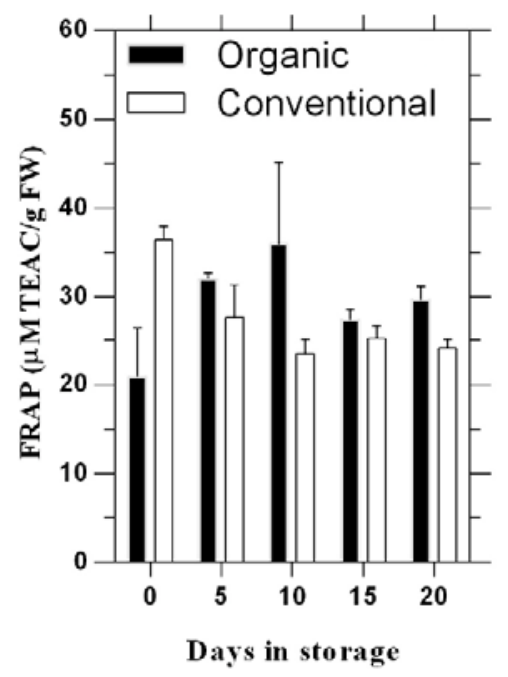

(B)

Figure 1. Changes in antioxidant activities by the DPPH (A) and FRAP (B) assays of tomato fruit during cold storage following production under organic and conventional production systems. Bars represent standard errors. * indicate the significant difference $(p \leq 0.05)$.

\subsection{Ferric Reducing Antioxidant Power (FRAP)}

FRAP values from both systems varied from 21 to $36 \mu \mathrm{M} \cdot \mathrm{TEAC} \cdot \mathrm{g}^{-1} \cdot \mathrm{FW}$ across storage days (Figure 1B), but the systems did not significantly differ.

\subsection{The Activity of SOD, CAT and APX}

SOD activity did not statistically differ between the two production systems across days of storage (Figure 2A). CAT activity did not differ between systems except at 15 days of storage when the organic system value was significantly greater than the conventional system (Figure 2B). No significant differences between systems were found for APX activity except that the organic value was significantly lower at 5 and higher at 10 days of storage than the conventional value (Figure 2C). 


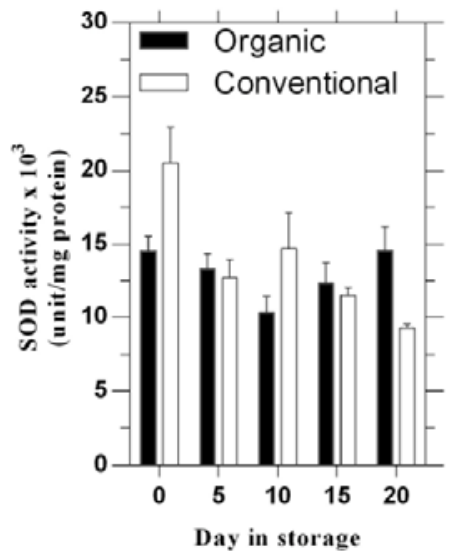

(A)

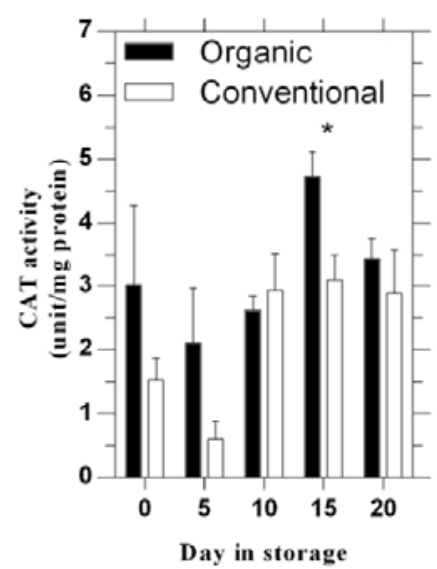

(B)

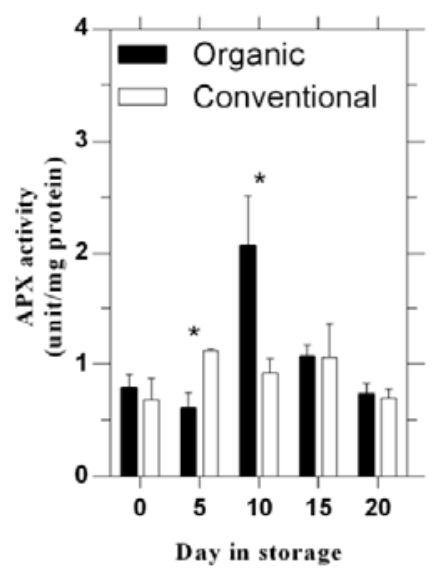

(C)

Figure 2. The activity of SOD (A), CAT (B) and APX (C) of tomato fruit during cold storage following production under organic and conventional production systems. Bars represent standard errors. * indicate the significant difference $(p \leq 0.05)$.

\section{Discussion}

Tomato fruit are a major source of phytochemicals and antioxidants such as lycopene, phenolics, flavonoids and vitamin C [24]. In this study, the antioxidant capacity of organic and conventional tomato during cold storage was compared using DPPH and FRAP radical scavenging capacity assays. These methods are based on electron transfer reactions which measure antioxidant reducing capacity [25]. Although DPPH activity was initially higher in conventional fruit through 10 days, it was lower than organic fruit at 15 and 20 days. In contrast, FRAP antioxidant activity did not differ between organic and conventional tomato fruit during storage. These two assays may have different sensitivities to the major antioxidants found in the fruit, as well as different reaction kinetics leading to the contrasting results [25]. Moreover, antioxidant effectiveness may depend on other factors such as polarity and solubility [26]. Some studies have reported significant correlations between the level of antioxidant activity and the phytochemical content of fruit [24,27]. Faller and Fialho [28] reported that organic tomato contained higher phytochemical contents than conventional tomato, but the assays in the present study gave conflicting results so it cannot be concluded that fruit from the two systems differed. No differences in DPPH assays were observed in other comparisons of organic versus conventional apple (Malus $x$ domestica Borkh.), mango (Mangifera indica L.) or orange (Citrus sinensis L.) [28,29]. The antioxidant capacity in organic or conventional fruits can be affected by cultural practices and environmental factors [4,5,9]. Riahi and Hdider [30] reported that organic fertilizer affected the antioxidant capacity in organic tomato. Similarly, Stracke et al. [31] demonstrated that the antioxidant capacity (FRAP, ORAC and TEAC assay) was not significant between organic and conventional apple.

SOD is a primary enzyme that eliminates superoxide radicles, converting them into dioxygen and hydrogen peroxide. Afterwards, hydrogen peroxide is catalyzed by CAT [12,13]. APX utilizes ascorbate as the electron donor reducing $\mathrm{H}_{2} \mathrm{O}_{2}$ to water, and prevents the accumulation of $\mathrm{H}_{2} \mathrm{O}_{2}$ to toxic levels under stress conditions [32]. In this study, the SOD activity did not significantly differ between fruit grown under the two cultural systems. In contrast, Oliveira et al. [33] reported that the activities of SOD and CAT were induced by organic production. In addition, no clear patterns in APX activity in organic or conventional tomato were evident.

\section{Conclusions}

The present study did not provide evidence that would indicate the superiority of nutritional composition of organically-grown tomato fruit in terms of antioxidant capacity by either the DPPH or 
FRAP assays, and also by antioxidant enzyme activities. Further work will be required to assess how differing maturities and harvest dates from each system affect these traits.

Acknowledgments: The authors would like to thanks Adams Enterprises, Ltd. for providing organic tomatoes and Postharvest Innovation Center, Commission on higher Education, Bangkok, Thailand for scientific instruments.

Author Contributions: Apiradee Uthairatanakij conceived and designed the experiments and also wrote the paper. Sukanya Aiamla-or performed the experiments and analyzed the data. Pongphen Jitareerat performed the experiments and review manuscript. AshariyaManeenoi contributed plant material production.

Conflicts of Interest: The authors declare no conflict of interest.

\section{References}

1. Zhao, X.; Carey, E.E.; Wang, W.; Rajashekar, C.B. Does organic production enhance phytochemical content of fruits and vegetables? Current knowledge and prospects for research. Horttechnology 2006, 16, 449-456.

2. Lombardi-Boccia, G.; Lucarini, M.; Lanzi, S.; Aguzzi, A.; Cappelloni, M. Nutrients and antioxidant molecules in yellow plums (Prunus domestica L.) from conventional and organic productions: A comparative study. J. Agric. Food Chem. 2004, 52, 90-94. [CrossRef] [PubMed]

3. Parka, Y.S.; Imb, M.H.; Choic, J.H.; Yimc, S.H.; Leontowiczd, H.; Leontowiczd, M.; Suhaje, M.; Gorinstein, S. The effects of ethylene treatment on the bioactivity of conventional and organic growing "Hayward" kiwi fruits. Sci. Hortic. 2013, 164, 589-595. [CrossRef]

4. Parka, Y.S.; Ham, K.S.; Kang, S.G.; Park, Y.K.; Namiesnik, J.; Leontowicz, H.; Leontowicz, M.; Ezra, A.; Trakhtenberg, S.; Gorinstein, S. Organic and conventional kiwi fruits, myths versus reality: Antioxidant, antiproliferative, and health effects. J. Agric. Food Chem. 2012, 60, 6984-6993. [CrossRef] [PubMed]

5. Worthington, V. Nutritional quality of organic versus conventional fruits, vegetables, and grains. J. Altern. Complement. Med. 2001, 7, 161-173. [CrossRef] [PubMed]

6. Winter, C.; Davis, S. Organic foods. J. Food Sci. 2006, 71, 117-124. [CrossRef]

7. Mehdizadeh, M.; Darbandi, E.I;; Naseri-Rad, H.; Tobeh, A. Growth and yield of tomato (Lycopersicon esculentum Mill.) as influenced by different organic fertilizers. Int. J. Agron. Plant Prod. 2013, 4, 734-738.

8. Reganold, J.P.; Andrews, P.K.; Reeve, J.R.; Carpenter-Boggs, L.; Schadt, C.W.; Alldredge, J.R.; Ross, C.F.; Davies, N.M.; Zhou, J. Fruits and soil quality of organic and conventional strawberry agro ecosystems. PLoS ONE 2010, 5, e12346. [CrossRef]

9. Toor, R.K.; Geoffrey, P.S.; Anuschka, H. Influence of different types of fertilizers on the major antioxidant components of tomatoes. J. Food Compos. Anal. 2006, 19, 20-27. [CrossRef]

10. Cano, A.; Acosta, M.; Arnao, M.B. Hydrophilic and lipophilic antioxidant activity changes during on-vine ripening of tomatoes (Lycopersicon esculentum Mill.). Postharvest Biol. Technol. 2003, 28, 59-65. [CrossRef]

11. Foyer, C.H.; Shigeoka, S. Understanding oxidative stress and antioxidant functions to enhance photosynthesis. Plant Physiol. 2011, 155, 93-100. [CrossRef] [PubMed]

12. Rani, P.; Unni, M.; Karthikeyan, J. Evaluation of antioxidant properties of berries. Indian J. Clin. Biochem. 2004, 19, 103-110. [CrossRef] [PubMed]

13. Bowler, C.; van Montagu, M.; Inze, D. Superoxide dismutase and stress tolerance. Annu. Rev. Plant Biol. 1992, 43, 83-116. [CrossRef]

14. Abreu, I.A.; Cabelli, D.E. Superoxide dismutases-A review of the metal-associated mechanistic variations. Biochim. Biophys. Acta 2010, 1804, 263-274. [CrossRef] [PubMed]

15. Willekens, H.; Chamnongpol, S.; Davey, M.; Schraudner, M.; Langebartels, C.; van Montagu, M.; Inzé, D.; van Camp, W. Catalase is a sink for $\mathrm{H}_{2} \mathrm{O}_{2}$ and is indispensable for stress defence in $\mathrm{C}_{3}$ plants. EMBO J. 1997, 16, 4806-4816. [CrossRef] [PubMed]

16. Kangasjärvi, S.; Lepistö, A.; Hännikäinen, K.; Piippo, M.; Luomala, E.M.; Aro, E.M.; Rintamäki, E. Diverse roles for chloroplast stromal and thylakoid-bound ascorbate peroxidases in plant stress responses. Biochem. J. 2008, 412, 275-285. [CrossRef] [PubMed]

17. Brandt, K.; Mølgaard, J.P. Organic agriculture: Does it enhance or reduce the nutritional value of plant foods? J. Sci. Food Agric. 2001, 81, 924-931. [CrossRef]

18. Brand-Williams, W.; Cuvelier, M.E.; Berset, C. Use of free radical method to evaluate antioxidant activity. Lebensm. Wiss. Technol. 1995, 28, 25-30. [CrossRef] 
19. Benzie, I.F.F.; Strain, J.J. The ferric reducing ability of plasma (FRAP) as a measure of "antioxidant power": The FRAP assay. Anal. Biochem. 1996, 239, 70-76. [CrossRef] [PubMed]

20. Cakmak, I.; Marschner, H. Magnesium deficiency and high light intensity enhance activities of superoxide dismutase, ascorbate peroxidase, and glutathione reductase in bean leaves. Plant Physiol. 1992, 98, 1222-1227. [CrossRef] [PubMed]

21. Nakano, Y.; Asada, K. Hydrogen peroxide is scavenged by ascorbate specific peroxidase in spinach chloroplast. Plant Cell Physiol. 1981, 22, 867-880.

22. Bartoli, C.G.; Simontacchi, M.; Guiamet, J.J.; Montadi, E.; Puntarulo, S. Antioxidant enzymes and lipid peroxidation during aging of Chrysanthemum morifolium RAM petals. Plant Sci. 1995, 104, 161-168. [CrossRef]

23. Kato, M.; Shimizu, S. Chlorophyll metabolism in higher plants, VII. Chlorophyll degradation in senescence tobacco leaves, phenolic-dependent peroxidative degradation. Can. J. Bot. 1987, 65, 729-735. [CrossRef]

24. Guil-Guerrero, J.L.; Rebolloso-Fuentes, M.M. Nutrient composition and antioxidant activity of eight tomato (Lycopersicon esculentum) varieties. J. Food Compos. Anal. 2009, 22, 123-129. [CrossRef]

25. Huang, D.; Ou, B.; Prior, R.L. The chemistry behind antioxidant capacity assays. J. Agric. Food Chem. 2005, 53, 1841-1856. [CrossRef] [PubMed]

26. Pokorny, J.; Yanishlieva, N.; Gordon, M. Antioxidants in Food: Practical Application; CRC Press: New York, NY, USA, 2001; p. 380.

27. Jin, P.; Wang, S.Y.; Wang, C.Y.; Zheng, Y. Effect of cultural system and storage temperature on antioxidant capacity and phenolic compounds in strawberries. Food Chem. 2011, 124, 262-270. [CrossRef]

28. Faller, A.L.K.; Fialho, E. Polyphenol content and antioxidant capacity in organic and conventional plant food. J. Food Compos. Anal. 2010, 23, 561-568. [CrossRef]

29. Bogs, J.; Bunning, M.; Stushnoff, C. Influence of biologically enhanced organic production on antioxidant and sensory qualities of (Malus $x$ domestica Borkh. cv. Braeburn) apples. Organ. Agric. 2012, 2, 117-126. [CrossRef]

30. Riahi, A.; Hdider, C. Bioactive compounds and antioxidant activity of organically grown tomato (Solanum lycopersicum L.) cultivars as affected by fertilization. Sci. Hortic. 2013, 151, 90-96. [CrossRef]

31. Stracke Berenike, A.; Rüfer, C.E.; Bub, A.; Seifert, S.; Weibel, F.P.; Kunz, C.; Watzl, B. No effect of the farming system (organic/conventional) on the bioavailability of apple (Malus domestica Bork. cultivar Golden Delicious) polyphenols in healthy men: A comparative study. Eur. J. Nutr. 2010, 49, 301-310. [CrossRef] [PubMed]

32. Salandanan, K.; Bunning, M.; Stonaker, F.; Kulen, O.; Kendall, P.; Stushnoff, C. Comparative analysis of antioxidant properties and fruit quality attributes of organically and conventionally grown melons (Cucumis melo L.). Hortscience 2009, 44, 1825-1832.

33. Oliveira, A.B.; Moura, C.F.H.; Gomes-Filho, E.; Marco, C.A.; Urban, L.; Miranda, M.R.A. The Impact of organic farming on quality of tomatoes is associated to increased oxidative stress during fruit development. PLOS ONE 2013, 8, e56354. [CrossRef] [PubMed]

(C) 2016 by the authors; licensee MDPI, Basel, Switzerland. This article is an open access article distributed under the terms and conditions of the Creative Commons Attribution (CC-BY) license (http://creativecommons.org/licenses/by/4.0/). 